\title{
Innovative activity and entrepreneurial rates in Mexico
}

\author{
Actividad innovadora y tasas de empredimientos en México \\ Enrique L. Kato-Vidal ${ }^{1 *}$ and Citlali Martínez Occhipinti² \\ ${ }^{1}$ Universidad Autónoma de Querétaro, México \\ ${ }^{2}$ Economista en Municipio de Corregidora, Querétaro, México
}

Received February 23, 2017; accepted September 13, 2017

Available online November 5, 2018

\begin{abstract}
The examination of entrepreneurial rates can provide information on the contribution of innovative activity to the local economy, given the functions of project selection and risk assessment. The goal of this paper is to evaluate entrepreneurial dynamics. Our hypothesis is that greater innovation activity offers more business opportunities, creating groups of entrepreneurs who will positively contribute to local economies. The GMM estimation was conducted by a dynamic panel with data from the 32 Mexican states from the 2005-2014 period. It was found that innovative activity, measured based on patenting and FDI, fosters the emergence of business-to-business (B2B) entrepreneurs. A significant innovation impact when grouping all entrepreneurs (consumers and industrial B2B markets) was not found. However, all entrepreneurs contributed positively as entrepreneurial capital to a greater per capita GDP. These results contribute to the literature on entrepreneurship and developing economies.
\end{abstract}

JEL code: $\mathrm{R} 11, \mathrm{O} 3, \mathrm{O} 1$

Keywords: Entrepreneurship ecosystem; Patents; FDI; B2B; Mexico

\footnotetext{
${ }^{*}$ Corresponding author.

E-mail address: enriquekato@uaq.mx (E.L. Kato-Vidal)

Peer Review under the responsibility of Universidad Nacional Autónoma de México.
} 


\section{Resumen}

Dadas las funciones de selección de proyectos y evaluación de riesgos, se puede obtener información sobre la contribución de la actividad innovadora a la economía local al estudiar las tasas de emprendimientos. El objetivo de este artículo es evaluar la dinámica emprendedora. Nuestra hipótesis es que la mayor actividad de innovación al ofrecer más oportunidades de negocio crea grupos de emprendedores que contribuyen positivamente a las economías locales. La estimación se realizó mediante GMM con un panel dinámico con los datos de los 32 estados de México del período 2005-2014. Se encontró que la actividad innovadora medida en base a las patentes y la IED promueve el surgimiento de emprendedores, negocio a negocio (B2B). No se encontró un impacto de la innovación al considerar a todos los emprendedores (tanto los del mercado de consumo como industrial -B2B-). Sin embargo, dado su capital gerencial, los emprendedores contribuyeron positivamente a un mayor PIB per cápita. Estos resultados contribuyen a la literatura sobre emprendedurismo y economías en desarrollo.

Código JEL: R11, O3, O1

Palabras clave: Ecosistema emprendedor; Patentes; IED; B2B; México

\section{Introduction}

In the last few decades, national governments and the international organizations have paid more attention to technological and innovative policies as a strategy for economic growth. The goal in Latin America is for expenditure on R\&D to surpass 1\% of the GDP in the short term. A literature review seems to show a twofold consensus: 1) technological innovation has a positive impact in income and 2) entrepreneurs are a key factor in such an impact (Wong et al., 2005). Nevertheless, in developing countries, there is no conclusive evidence regarding the impact of an innovative region on the emergence of entrepreneurs and greater economic growth (WEF, 2015a).

This paper analyzes whether innovative activity (i.e., patents and foreign investment) affects entrepreneurship rates or not. Our approach consists of examining whether greater innovative activity encourages or inhibits more entrepreneurship activity. In this regard, there are opposite predictions. One study (Audretsch et al., 2001) predicts that entrepreneurs emerge as a consequence of adverse job market conditions (i.e., high unemployment), and thus, there may not be a link between the entrepreneurship rate and innovation activity. By contrast, other authors, following the ideas of the Schumpeterian entrepreneurial function, argue that entrepreneurs constitute the productive sector by exploiting market opportunities from new technologies. "Economic development, [in J. Schumpeter's view], had to be seen as a process of qualitative change, driven by innovation, taking place in historical time" (Fagerberg, 2005, p. 6). Based on an examination of count data on innovation from the US Small Business Administration (SBA), Acs et al. (2002) found that "patents might be a reliable measure of innovation at the regional level", given that "knowledge flows are indeed bounded within geographic limits" (p. 1071). This notion suggests that there may be a positive relationship between entrepreneurial activity and innovation. Among the main sources of foreign technology, especially for developing countries, foreign direct investment (FDI) often plays a key role (WEF, 2015b, p. 36). However, the impact of FDI is not always positive, especially 
when "the demand-pulling effect is not large enough to compensate the competition effect" (Barbosa et al., 2009, p. 330). These authors show that the initial impact of FDI in Portugal is positively significant at the $10 \%$ level but that the benefits initially obtained are negated by the subsequent increase in foreign capital firms, a fact substantiated by data from the 19862000 period. Accordingly, the conclusion might be drawn that entrepreneurial activity may grow in economies with greater foreign direct investments, provided that a positive externality associated with an increase in the demand of intermediate goods from foreign capital firms persists. Although previous perspectives contribute to a better understanding of this problem, we posit that innovative activity occurs amid a diverse economic context of modern sectors that are integrated into global production chains and traditional sectors that depend on the buying power of consumers in local markets.

Weak economic and employment growth has put entrepreneurship back on policy agendas throughout the world. Self-employment is expected to grow and, through entrepreneurship, reduce high unemployment. When possible, entrepreneurs may replace the hiring of staff typically done by large companies. According to estimations, the employment growth rate in Latin America has slowed in the recent period [2009-2013] compared to the two previous decades [1990-2008] (ECLAC, 2014, pp. 127-128). Although the general employment rate has not increased, there are "specific problems hindering young people's access to jobs" (ECLAC, 2014, p. 147). However, promoting new ventures is not a simple strategy to which the occupational choice model may offer an answer. Poschke (2013) provides an analysis in which people who become entrepreneurs belong to both the low- and high-ability groups and in which subsidy policies should ensure that new ventures come from both groups, given that productivity may not increase if the newcomers stem from the lower end and many small firms will remain small. Therefore, we propose that the greater the proportion of entrepreneurs from the high-ability group (those capable of increasing a firm's productivity, size, and value), the greater the impact of an innovative activity that will be reflected in the rate of ventures.

Explaining entrepreneurial activity requires economic and innovation variables to identify the contribution of innovation activity to domestic entrepreneurship. It has been found that under a favorable institutional framework, there is an increase in the positive impact of entrepreneurship on economic growth (Amahouss and Ibourk, 2013). In addition, it has been found that in economies with relatively strong institutions, informality (shadow economy) may be an intermediate stage for entry with new businesses that initially grow informally and then transfer to the formal sector. In general, Estrin and Mickiewicz (2012, p. 562) argue that "a combination of limited informality and low-cost opportunities to transfer to formality is likely to encourage entrepreneurial entry". This position implies that to evaluate the entrepreneurship rate in developing countries, it is important to consider the presence of informality because it may bias the impact of innovative activity on the emergence of entrepreneurs. The issue concerns not only the behavior of entrepreneurs in a given economy but also the opportunities that are available to them. Audretsch and Keilbach (2007) note that there are more opportunities in contexts with a high level of knowledge, where entrepreneurs perform the function of knowledge spillovers while invigorating economic growth.

In the empirical research we present, we explore the relationships of foreign direct investment per capita, the patent rate, per capita income, the percentage of informality, and the entrepreneurial rate. The data correspond to the 32 Mexican states for the 2005-2014 period. 
The data selection is appropriate because it makes it possible to evaluate the innovative activity for both innovative and traditional entrepreneurs (see Audretsch and Keilbach, 2007). The degree of informality is controlled, given the incentive that it may exert on the entrepreneurial process (see Estrin et al., 2012). To measure innovative activity, we track patents in the region (see Modrego et al., 2015; Acs et al., 2002).

F. Modrego et al. assume that an innovation is realized once a free entrepreneur matches an invention and that the individual probability of matching is a function of the knowledge intensity (i.e., the stock of inventions available per entrepreneur) in the regional economy. They also note that patent counts could underestimate local innovation (2015, p. 687). We use patent counts because patents constitute an intermediate output of knowledge production and are proxies for knowledge that can be commercialized (Block et al., 2013, p. 702). In a study for Ireland, Roper et al. (2015) find that very few firms are patent-active: an average of 5\% of firms had made successful patent applications, and many of these were single-patent firms.

However, alongside in-house knowledge investments, firms also engage in an external search for knowledge for innovation. External search was defined as the number of different partner types with which firms had innovation cooperation. A positive impact on both the probability of innovating and innovation success was observed when the innovation effect of knowledge flows is derived from external search (Roper et al., 2015, p. 1338). The researchers conclude that existing knowledge stocks (patents) do have a positive effect on the innovation value of knowledge flows related to external search. We expect higher startup rates in regions with greater investments in new knowledge, such as FDI and patents. Block et al. (2013, p. 697) claim that opportunities for entrepreneurship are superior when the ability to access knowledge spillovers from geographically proximate sources is greater.

Our research question is as follows: given the market conditions (i.e., income level), are there domestic capabilities that promote a higher rate of startups linked to innovation? Consequently, we want to determine the impact of entrepreneurs on economic growth. This study contributes to the literature on entrepreneurs and innovation in developing countries by showing that innovative activities positively affect B2B entrepreneurs and economic growth through the entrepreneurial capital. Most empirical studies analyze information from a sample of countries and with only one measure of innovation. We believe that our approach with two measures of innovation adds valuable insights to the literature. The following section presents the posited hypothesis concerning entrepreneurship, the economic variables, and innovation activity.

\section{Innovative activity, growth, and entrepreneurship}

\section{The role of knowledge in entrepreneurship}

P. Wong et al. (2005) distinguish two kinds of entrepreneurs: those who are driven by the search for an income (business opportunity) and those driven by a lack of job opportunities (necessity). The authors assume that individuals who engage in Opportunity Total Early-Stage Entrepreneurial Activity (TEA) have more endowments of human capital and entrepreneurial activity to sustain new business ventures that will contribute to growth, similar to B2B entrepreneurs. Their hypothesis is that Opportunity TEA rates reflect the existence of economic rent that ideally arises from implementing or creating knowledge and technology. Therefore, 
they claim that High Opportunity TEA rates will be associated with high growth (p. 340). The main finding from this analysis is the significance of High Potential TEA as the sole form of entrepreneurship that has any explanatory effect on differing rates of economic growth across nations (p. 345). The authors highlight that the coefficient of the innovation variable is slightly larger when the rate of High Potential Entrepreneurs is used (pp. 342-343).

The knowledge variable is among the most significant, given that the greater the investment in knowledge, the greater the emergence of ideas that can be marketed, thus promoting the creation of new entrepreneurs. Some proportion of knowledge is typically marketable. In abstract terms, Audretsch and Keilbach (2007) posit the existence of a knowledge filter that determines how much of the technological knowledge will become innovative goods and services for the market. Therefore, an investment that promotes new ideas through knowledge transfer is the determining variable of output in endogenous models.

In particular, a distinction should be made between two types of entrepreneurs so that , where is traditionally based entrepreneurial activity (i.e., market size), and is knowledge-based entrepreneurial activity. Audretsch et al. (2007) explain that the key determinant for is the economic growth rate, . By contrast, to explain activity, two factors are proposed: investment in new knowledge, , and a knowledge filter, , which quantifies the portion of knowledge that the market demands, i.e., the ratio between the available knowledge and its marketability. The potential profit can be expressed as a function with three arguments, , where is the key variable for traditional entrepreneurs, and the pair is the explanatory variable for technology-based entrepreneurs, .

Thus, it may be presumed that there will be more entrepreneurs as the opportunities to obtain profits $\left(\pi^{*}\right)$ grow and fewer entrepreneurs as the undertaken opportunity cost rises. Formally, $E=\left(\pi^{*}-w\right)$, where $w$ is the current market salary, which represents the income foregone for starting an entrepreneurial activity. A complete specification includes the barriers that inhibit the development of innovative activity, such as financial restrictions, risk aversion, bureaucratic restrictions, and the lack of social acceptance. Thus, the function for the total entrepreneurial activity could be expressed as follows:

$$
E=\left(\frac{1}{\beta}\right)\left(\pi^{*}\left(g_{y}, K, \theta\right)-w\right)
$$

where $\beta$ is the friction that reflects the impediments or barriers to entrepreneurial activity.

Although it is not key for entrepreneurs to have a given educational level, experimentation and evaluation are needed as factors to develop an entrepreneurial sense, which is the reason entrepreneurial and innovation clusters are important factors for development. Urban agglomeration acts on greater productivity rates due to the concentration of more-qualified people who have the benefit of more governability in the region, which translates into better public services. A city with high productivity often has higher levels of knowledge and human capital (Glaeser and Resseger, 2010). Chatterji, Kerr, and Glaeser (2013) study strategies for fostering entrepreneurship, including lower taxes to start a business, cost-free public infrastructures, and credit support, i.e., the government has the ability to promote ventures to ensure the success of firms, which will result in the collection of more taxes in the future. 


\section{Growth and entrepreneurship}

In the literature, authors agree that the entrepreneurship rate contributes to economic growth. However, to strengthen its impact, it is necessary to take into account certain indicators that interact with entrepreneurial activity and that create favorable conditions for opening businesses. One such indicator that affects economic growth, based on the entrepreneurial rate, is the institutional framework. In a study with panel data from some countries that belong to the OECD, Amahouss and Ibourk (2013) initially analyze the relationship between the investment rate in physical capital and three entrepreneurial variables: the startup rate, the percentage of new firm owners, and total entrepreneurial activity. It is shown that with economic growth, the latter two entrepreneurial variables have a significantly positive relationship with per capita GDP, whereas the startup variable, although showing a positive relationship, is not significant.

In a second analysis, Amahouss and Ibourk (2013) add variables to the panel data from the institutional framework. These variables include a population logarithm, a consumer price index logarithm, and an economic openness logarithm, measured based on the export plus import rates. This time, the startup variable is found to be positive and significant. Once the variables considered as the institutional framework have been aggregated, the ratio for new firm owners and total entrepreneurship and economic growth are strengthened as well. In addition to obtaining the relationship between entrepreneurship and GDP, Amahouss and Ibourk (2013) analyze the innovation level - measured based on patent applications per resident, a variable that has an impact on economic welfare. A greater significance for the entrepreneurs and the institutional framework variable is found.

Using data form Germany, Audretsch and Keilbach (2007) estimate the contributions of entrepreneurs to economic growth and explain the variables that affect entrepreneurial activity. They find that capital and the labor force contribute to economic growth, as does entrepreneurship. Their exogenous variables are physical capital, labor, knowledge capital, general entrepreneurship, high-tech entrepreneurship, ICT entrepreneurship, and low-tech entrepreneurship. In attempting to explain entrepreneurial activity endogenously, they find that economic growth has a positive impact, although at the $10 \%$ significance level, on both general entrepreneurship and high-technology entrepreneurship. An increase in R\&D intensity will have a positive and significant effect in boosting high-technology and information and communication technology entrepreneurs. Investment in physical capital shows a reduction in knowledge-based entrepreneurship; greater unemployment rates have the same effect. The authors conclude that high growth but relatively low investment are signs of a higher input of knowledge-based entrepreneurship.

Considering a country with low levels of R\&D, we could assume that the most frequent type of innovation would be process and service innovation, especially in sales departments. Those innovations occur in low-growth markets, low-market-share firms and when incumbent and entrant firms compete strongly. In a detailed study of Chinese B2B firms, M. Beverland et al. (2006) show a broad range of ways to innovate, from firms with R\&D activities devoted to product innovation to process innovation and strong adaptive ability, as well as firms with sales innovation, seen as customer service and low profit margins. It is also important to note that service innovation is different from manufacturing innovation (Salunke et al., 2013: 1086). Service innovation is due to the external linkages integrating customers, employees, and 
suppliers. Additionally, Salunke et al. (2013) find that market-based innovation is possible for small firms if they can effectively utilize scarce resources in constraining environments.

\section{Data and definitions of variables}

The data we used to construct the entrepreneurial rate came from the National Institute of Statistics and Geography (Inegi, by its initials in Spanish) through an employment survey that obtains information by surveying homes. The survey has a national reach and covers all 32 states. The category reported as entrepreneurs consists of people who classify themselves as employers, that is, people who are both self-employed and have people working for them. In the calculations presented, we do not include self-employed people who were not employers.

The treatment in which the information is processed allows us to differentiate entrepreneurs whose main client is the consumer (B2C) from those whose clients are mainly firms (B2B) or intermediaries. In contrast to the consumer market, where one large seller needs to reach many individual customers, in the B2B market, the buyer and seller are both organizations. The particular characteristics of the B2B market are the following: a) the buyer is often larger than the seller and has the power to influence the exchange process, b) every customer is more important than in consumer markets, c) the focus is not on single transactions but on longterm interactions, and d) the offer and the information flow between seller and buyer are more complex than in consumer markets (Andersson, 2006: 39-40). For these reasons, a separate estimate for B2B entrepreneurs is proposed.

The labor informality rate, which affects the volume of entrepreneurs in an economy, was also obtained from the employment survey. The informality measure obtained is an indicator declared by the informant, not an estimation, as in Estrin et al. (2012), who collect a set of factors. The third and last variable used based on the employment survey is the entrepreneurial opportunity cost. Instead of using only the average worker's salary as an opportunity cost, we use the relative worker income, calculated as the worker's salary divided by employer income. This change in the opportunity cost allows us to reduce the errors caused by informant underreporting and difficulties in the collection of field data.

To explain entrepreneurial innovation activity, FDI and patent applications were considered, both in per capita terms. We expect that, in a given region, the higher the number of foreign capital firms, the greater the development of new managing skills, local businesses, and overall productive modernization. Barbosa and Eiriz (2009) use data from Portugal to find a weak but positive impact. By including patent applications, the innovation capacity in a territory was revealed (Acs et al., 2002). Although the Mexican economy is not characterized by its high innovation rates, it is possible to find nodes of technological development that lead us to ask whether knowledge generation has an impact on the creation of ventures or not (RodríguezPose et al, 2015; Germán-Soto et al, 2009).

The highest foreign investment is located in the northern industrialized states. In contrast, patenting activity is mainly focused in the center of the country and in some states on the border with the United States. The map of Rodríguez-Pose et al. (2015, p. 179) complements this information by showing the geographical distribution of R\&D expenditure (\% GDP) in Mexico. B2B entrepreneur activity is widely distributed throughout the country, with higher 
rates in some coastal states from both east and west. The southern part of the country, the farthest from the border with the U.S.A., is the lowest in patents and FDI.

Lastly, to estimate a production function with the entrepreneurial capital measurement of human capital, the rate of graduate students receiving scholarships from the federal government was included as a regressor. As a measurement of knowledge capital, public R\&D financing for large firms was also included as a regressor. The definitions and descriptive statistics for all of the variables are presented in Table 1 below.

Table 1.Definitions of Variables

\begin{tabular}{|c|c|}
\hline $\begin{array}{l}\text { Rate of Total Entrepreneurs } \\
\text { Rate of B2B Entrepreneurs }\end{array}$ & $\begin{array}{l}\text { : The rate of employers per } 1000 \text { inhabitants. Source: National Institute of Statistics } \\
\text { and Geography (Inegi), Mexico. } \\
\text { : The employer rate per } 1000 \text { inhabitants who sell their merchandise not directly to }\end{array}$ \\
\hline $\begin{array}{l}\text { Foreign Direct Investment } \\
\text { (FDI) }\end{array}$ & $\begin{array}{l}\text { the public but to other firms or intermediaries. Source: Inegi, Mexico. } \\
\text { : US dollars per capita. Source: National Registry of Foreign Investment (RNIE), }\end{array}$ \\
\hline Shadow Rate & Mexico. \\
\hline Opportunity Cost & : The informal labor rate (\% economically active population). \\
\hline GDP per capita & : The ratio of average wages to employer income. Source: Inegi \\
\hline Patents & $\begin{array}{l}\text { : Gross Domestic Product (GDP) per capita, MXP, } 2010=100 . \\
\text { : The number of patents requested per every } 100000 \text { inhabitants. }\end{array}$ \\
\hline Knowledge Capital & Factors of production \\
\hline Human Capital & $\begin{array}{l}\text { R\&D. Innovation Incentive Public Budget (PEI - Presupuesto Público de Estímulo } \\
\text { a la Innovación) per capita }(2010=100) \text {. } \\
\text { : The graduate scholarship holder rate, as a proportion of the population. Source: } \\
\text { Conacyt, Mexico. }\end{array}$ \\
\hline
\end{tabular}

Table 2. Summary Statistics $(\mathrm{n}=320)$

\begin{tabular}{lllll}
\hline Variable & Mean & Std. Err. & [95\% Conf. Interval] \\
\hline Total Entrepreneurs (per 1,000 inhabitants) & 19.92 & 0.77 & 18.36 & 21.48 \\
B2B Entrepreneurs (per 1,000 inhabitants) & 3.93 & 0.25 & 3.42 & 4.44 \\
FDI (US dollars per capita) & 186.46 & 51.40 & 81.61 & 291.29 \\
Shadow Rate (\%) & 53.64 & 1.80 & 49.98 & 57.31 \\
Average Wages / Employer Income & 0.570 & 0.011 & 0.547 & 0.593 \\
GDP per capita (MXP, 2010=100) & 124547.3 & 24911.2 & 73740.6 & 175354.1 \\
Patents (per 100,000 inhabitants) & & & & \\
\hline
\end{tabular}




\section{Estimation issues and specification}

It is assumed that entrepreneur income $R$ is positively correlated with the per capita GDP (y) and knowledge capital $(\tau)$, as proposed by Audretsch and Keilbach (2007). In turn, $R$ is positively correlated with the presence of foreign direct investment $\left(K^{f}\right)$ and the shadow economy size $(S)$; thus, we can posit that $R\left(y, \tau, K^{f}, S\right)$. In the case of FDI, Barbosa and Eiriz (2009) document that a larger foreign investment flow can promote or inhibit a larger number of ventures, depending on the dominance of a bandwagon effect (linkages) or a competition effect. Overall, Barbosa and Eiriz conclude that the effect is weakly positive. Regarding the impact on the informal economy, there is mixed evidence on ventures as well. In theory, Estrin and Mickiewicz (2012) assume that the impact is negative, although they also acknowledge that in some cases the impact may be positive: "In some contexts, the shadow economy will grease the wheels of bureaucracy; participation in the formal sector may come with such a high opportunity cost that opening up opportunities in the informal sector may actually increase entry" (p. 562). They add that "the shadow economy may offer an alternative option for entry, thereby facilitating the (second best) productive use of entrepreneurial talent".

Entrepreneurship combines individual-specific ability with an upfront investment to generate an uncertain return (Gentry and Hubbard, 2000). Consider a risk-neutral individual $i$ considering entrepreneurial entry at time $t$. If the individual works for a firm, then he or she receives a certain wage, . Entrepreneurial ability is indexed by . With an investment of , the gross returns from entrepreneurship are given by if a project is successful, and the gross returns are zero if the project is unsuccessful. Letting represent the probability of success and the gross risk-free interest rate, individual 's expected net return from entrepreneurship is given by:

$$
\pi_{s}\left(\theta_{i} k_{i t}^{\alpha}-r k_{i t}\right)-\left(1-\pi_{s}\right) r k_{i t}, \text { or } \pi_{s} \theta_{i} k_{i t}^{\alpha}-r k_{i t}
$$

For entrepreneurial selection, individual $i$ compares the expected returns to entrepreneurship and employment, choosing entrepreneurship if $R_{t}=\pi_{s} \theta_{i} k_{i t}^{\alpha}-r k_{i t}>w_{i t}$. The (possibly negative) net gain, $G$, from entrepreneurship (as opposed to being employed) is defined by $G_{t}=\pi_{s} \theta_{i} k_{i t}^{\alpha}-r k_{i t}-w_{i t}$. Note that the wage, $W$, accruing from employment depends (negatively) on the number of workers. If the level of employment is high, then the wage is low. At a high level of employment, the wage is very low. Therefore, the net gain from entrepreneurship is positive, Gt $>0$; thus, everyone elects to be an entrepreneur. When the wage is high, everyone wants to work because Gt $<0$; It follows from these remarks that, in equilibrium, the net gain from entrepreneurship must be precisely zero, Gt $=0 ;$. Only then is it the case that there is no incentive for anyone to change his or her behavior.

\section{GMM estimation}

We use Arellano and Bond's difference-GMM estimators based on the following assumptions. The entrepreneur rate is a dynamic process, with current realizations of the entrepreneur rate influenced by past realizations. There are arbitrarily distributed fixed entity 
effects, with the entrepreneur rate being consistently higher for some entities than for others. The determinants of the entrepreneur rate may be endogenous. Given the model specification, the number of time periods of available data may be small. In this setting, it is assumed that there are no good instruments available outside the current dataset: the only instruments are intrinsic to the dataset and are based on lags of the instrumented variables.

Linear dynamic panel data models include $p$ lags of the dependent variable as covariates and contain unobserved panel-level effects that are either fixed or random. By construction, the unobserved panel-level effects are correlated with the lagged dependent variables, making standard estimators inconsistent. Arellano and Bond (1991) derive a consistent generalized method of moments (GMM) estimator for this model. The Arellano and Bond estimator can perform poorly if the autoregressive parameters are too large or the ratio of the variance in the panel-level effect to the variance in idiosyncratic error is too large. Building on the work of Arellano and Bover (1995), Blundell and Bond (1998) develop a system estimator that uses additional moment conditions. We use this estimator, which is designed for datasets with many panels and few periods. This method assumes that there is no autocorrelation in the idiosyncratic errors, and it requires the initial condition that the panel-level effects be uncorrelated with the first difference of the first observation of the dependent variable.

We use a two-step GMM estimator that estimates the covariance matrix of the moment conditions using the first-step residuals. Consider the following dynamic panel-data model:

$$
E_{i t}=\sum_{j=1}^{p} \alpha_{j} E_{i, t-j}+x_{i t} \beta_{1}+w_{i t} \beta_{2}+v_{i}+\epsilon_{i t}
$$

$i=1, \ldots, 32 . \quad t=1, \ldots, 10$. Where the $\alpha_{\mathrm{j}}$ are $p$ parameters to be estimated, the $\beta$ are also parameters to be estimated, $i$ represents the entities or panels, $t$ represents the time variable, $x_{i t}$ is an exogenous covariate, $w_{i t}$ is a predetermined or endogenous covariate (see foot text of table 3 for the variables' exogeneity used in the estimations), and $\epsilon_{i t}$ are i.i.d. over the entire sample with variance. The and the are assumed to be independent for each $i$ over all $t$. The Sargan test for overidentifying restrictions is performed to test for the validity of the instruments.

\section{Econometric results}

\section{Entrepreneurial rates}

An equation was estimated to find the determinants of entrepreneurial activity. The sample was constructed with panel data from the 32 Mexican states from the 2005-2014 period. Table 3 contrasts two specifications and shows the results. Specification II describes the data behavior with more precision. Specification I (which includes the informality rate) is weakly significant. Including informality leads to an overestimation of the real entrepreneurship rate, possibly due to the co-linearity with the per capita GDP. A highly significant relationship between informality and GDP is observed in the correlation matrix.

The estimated specification II coefficient is used in the following analysis. The results confirm that the evolution of the total entrepreneurship rate is essentially explained by per capita GDP, combined with the autoregressive term and the opportunity cost. In other research on 
investment in Mexico, it has been concluded that the existence of more business opportunities (i.e., greater GDP) is a more important determinant of capital formation than the return rate (Kato-Vidal, 2015: 486). However, to explain the variations in the B2B entrepreneurship rate, FDI and patent variables are required.

To evaluate the impact of the explanatory variables for the entrepreneurship rate, values from the interquartile range are used. We believe that the interquartile range is an appropriate measurement for sample dispersion that can provide useful information for other Latin American economies. The data show that the total entrepreneurship rate increases from 17.21 entrepreneurs (per 1000 inhabitants) in quartile 1 to 21.67 in quartile 3. The interquartile increase in B2B entrepreneurs is smaller in absolute terms, although their growth is similar in relative terms (1.26 times). It is important to highlight that the interquartile growth of FDI triples (from $\$ 61.15$ to $\$ 188.99$ USD per capita) and that the GDP and patents nearly double, at 1.81 and 2.11 times, respectively. We consider these variations to be very useful when evaluating the consistency of estimations.

Table 3 Determinants of the Entrepreneurial Rate: GMM Estimations

\begin{tabular}{|c|c|c|c|c|}
\hline & \multicolumn{2}{|c|}{$\begin{array}{l}\quad[\mathrm{I}] \\
\text { With informal workers }\end{array}$} & \multicolumn{2}{|c|}{$\begin{array}{l}\quad[\mathrm{II}] \\
\text { Without informal workers }\end{array}$} \\
\hline & Total & $\mathrm{B} 2 \mathrm{~B}$ & Total & $\mathrm{B} 2 \mathrm{~B}$ \\
\hline \multirow[t]{2}{*}{ Et-1 } & 0.806 & 0.803 & 0.746 & 0.763 \\
\hline & $(13.50)^{* * *}$ & $(10.29)^{* * *}$ & $(14.26)^{* * *}$ & $(8.23)^{* * *}$ \\
\hline \multirow[t]{2}{*}{ E t-2 } & -- & -0.122 & -- & -0.2 \\
\hline & -- & $(-1.42)$ & -- & $(-2.25)$ \\
\hline \multirow[t]{2}{*}{ FDI per capita } & 0.00015 & 0.00023 & 0.00018 & 0.00017 \\
\hline & $(0.41)$ & $(2.60) * * *$ & $(0.61)$ & $(1.96)^{* *}$ \\
\hline \multirow[t]{2}{*}{ Shadow Rate } & 0.541 & 0.0295 & -- & -- \\
\hline & $(1.91)^{*}$ & $(1.63)^{*}$ & -- & -- \\
\hline \multicolumn{5}{|c|}{ Ratio of Average Wages to Employer } \\
\hline \multirow[t]{2}{*}{ Income } & -8.005 & -3.182 & -8.587 & -2.732 \\
\hline & $(-3.61)^{* * *}$ & $(-4.92)^{* * *}$ & $(-4.07)^{* * *}$ & $(-4.46)^{* * *}$ \\
\hline \multirow[t]{2}{*}{ GDP per capita } & $1.30 \mathrm{E}-06$ & $3.44 \mathrm{E}-07$ & $1.53 \mathrm{E}-06$ & $4.70 \mathrm{E}-07$ \\
\hline & $(1.65)^{*}$ & $(1.09)$ & $(2.29)^{* *}$ & $(1.61)^{*}$ \\
\hline \multirow[t]{2}{*}{ Patents per capita } & 0.156 & 0.107 & 0.073 & 0.119 \\
\hline & $(0.47)$ & $(1.82)^{*}$ & $(0.28)$ & $(1.64)^{*}$ \\
\hline \multirow[t]{2}{*}{ Constant } & 5.103 & 1.277 & 9.595 & 3.052 \\
\hline & $(2.29) * *$ & $(1.22)$ & $(5.58)^{* * *}$ & $(3.55)^{* * *}$ \\
\hline Wald test & {$[0.000]$} & {$[0.000]$} & {$[0.000]$} & {$[0.000]$} \\
\hline Sargan test & {$[1.000]$} & {$[1.000]$} & {$[1.000]$} & [0.9999] \\
\hline First-order serial correlation & {$[0.0001]$} & {$[0.0002]$} & {$[0.0001]$} & {$[0.0001]$} \\
\hline Second-order serial correlation & {$[0.8167]$} & {$[0.0621]$} & [0.9047] & {$[0.1083]$} \\
\hline Observations & 288 & 256 & 288 & 256 \\
\hline Entities & 32 & 32 & 32 & 32 \\
\hline
\end{tabular}


Authors' calculations. Source: See Table 1. Notes: $t$-statistics in parentheses, $* * *$ indicates that a coefficient is significant at the $1 \%$ level, ** significant at the $5 \%$ level, * significant at the $10 \%$ level. Numbers in square brackets indicate p-values. Stata GMM system estimator. Robust std error. Arellano-Bover/Blundell-Bond linear dynamic panel data estimation. Predetermined: FDI per capita. Exogenous: Patents per capita. Endogenous: Shadow rate, GDP per capita, and the ratio of average wages to employer income. Under the null hypothesis that the instruments are not correlated with the error process, the Sargan test cannot reject the validity of the instruments. The Sargan test indicates that all of the models are identified (p-values are 1). Therefore, the specifications satisfy all of the requirements to yield Arellano and Bond estimates that are consistent. The tests of serial correlation in the first-differenced residuals are significant for all model specifications: there is serial correlation. The AR (2) test fails to reject the null hypothesis that the first-differenced error term is not second-order serially correlated.

Table 4. Entrepreneurs and Their Determinants in the Interquartile Range Panel A. Relative Relevance of Determinants for Entrepreneurship (Percentages calculated with data from panel B)

\begin{tabular}{|c|c|c|c|c|}
\hline & \multicolumn{2}{|c|}{ Short-term } & \multicolumn{2}{|c|}{ Long-term } \\
\hline & Total & $\mathrm{B} 2 \mathrm{~B}$ & Total & $\mathrm{B} 2 \mathrm{~B}$ \\
\hline [A] IQR (rate per 1,000 inhab.) & $100 \%$ & $100 \%$ & & \\
\hline$[\mathrm{B}]=(1+2+\ldots+5)$ & $86.1 \%$ & $84.2 \%$ & $100.0 \%$ & $100.0 \%$ \\
\hline (1) Autoregressive term & $74.6 \%$ & $56.3 \%$ & & \\
\hline (2) FDI per capita & & $2.5 \%$ & & $7.7 \%$ \\
\hline $\begin{array}{l}\text { (3) [Opp. Cost] Ratio of Average Wages to } \\
\text { Employer Income }\end{array}$ & $9.9 \%$ & $16.3 \%$ & $86.0 \%$ & $91.2 \%$ \\
\hline (4) GDP per capita & $1.6 \%$ & $2.6 \%$ & $14.0 \%$ & $1.1 \%$ \\
\hline (5) Patents per capita & & $6.5 \%$ & & $36.3 \%$ \\
\hline Error $[=\mathrm{A}-\mathrm{B}]$ & $13.9 \%$ & $15.8 \%$ & & \\
\hline
\end{tabular}

Panel B. Estimated Impacts Using Values from the Interquartile Range $(\beta \times I Q R)$

\begin{tabular}{|c|c|c|c|c|}
\hline & \multicolumn{2}{|c|}{ Short-term } & \multicolumn{2}{|c|}{ Long-term } \\
\hline & Total & $\mathrm{B} 2 \mathrm{~B}$ & Total & $\mathrm{B} 2 \mathrm{~B}$ \\
\hline [A] IQR (rate per 1,000 inhab.) & 4.460 & 0.860 & & \\
\hline$[\mathrm{B}]=(1+2+\ldots+5)$ & 3.841 & 0.724 & 2.022 & 0.885 \\
\hline (1) Autoregressive term & 3.327 & 0.484 & & \\
\hline (2) FDI per capita & & 0.022 & & 0.050 \\
\hline $\begin{array}{l}\text { (3) [Opp. Cost] Ratio of Average Wages to } \\
\text { Employer Income }\end{array}$ & 0.442 & 0.140 & 1.738 & 0.592 \\
\hline (4) GDP per capita & 0.072 & 0.022 & 0.283 & 0.007 \\
\hline (5) Patents per capita & & 0.056 & & 0.236 \\
\hline Error $[=\mathrm{A}-\mathrm{B}]$ & 0.619 & 0.136 & & \\
\hline
\end{tabular}

Authors' calculations. Source: See Table 3. 
Table 4 shows a summary of the findings. Only the data for coefficients with statistical significance are shown. In panel A, estimations are expressed in percentage terms to facilitate the comparison between total and B2B entrepreneurs. The analysis of the results reveals that the total entrepreneurship rate is a process with great inertia, driven to a small extent by changes in per capita GDP and whose main component is labor through salary opportunity costs. The weakness of the labor market, expressed in relatively low salaries, promotes the emergence of entrepreneurship, particularly B2B entrepreneurs. However, the evolution of B2B entrepreneurs has less inertia and although it also positively depends on GDP growth, its main determinants are the patent rate and the presence of foreign capital (FDI).

\section{GDP and entrepreneurs}

In the previous section, an estimation of the determinants for the entrepreneurship rate was obtained; in the present section, we proceed to evaluate the entrepreneur contribution to the per capita GDP, a common development indicator. The procedure has two parts. First, a production function is parametrized to estimate the contribution of entrepreneurial capital (Table 5); then, data from quartiles from the sample are used to evaluate the per capita GDP growth attributable to the growth of the entrepreneurship rate (Table 6). It is found that the per capita GDP from quartile 4 is $4.5 \%$ greater with respect to quartile 1 due to the presence of a higher rate of entrepreneurs. As in the previous section, the estimation entails a GMM two-step dynamic panel data method. The standard errors reported are robust. All of the explanatory variables are taken as predetermined. Two estimations are made: one for the total number of entrepreneurs and another for B2B entrepreneurs. Both variables prove positive and highly significant. Compared to the group of total entrepreneurs (Table 5), the impact on the per capita GDP of B2B entrepreneurs is $+15 \%(=/=696.1 / 606.4)$.

To estimate the function of production, including entrepreneurial capital, all of the variables are expressed in per capita or per worker terms. Given the scarcity of information regarding the total amount of physical capital, foreign direct investment (FDI) per capita is used as a proxy variable. Additionally, the amount per capita of public financing for the promotion of innovation $(\mathrm{R} \& \mathrm{D})$ is included as a regressor. This is a comprehensive mix composed of public and private resources for technological innovation business projects. As a third explanatory variable, the rate per capita of individuals engaged in graduate studies is incorporated as human capital (). The variable descriptions are shown in Table 1 . Both R\&D and are positive and highly significant. FDI is only significant in the presence of the B2B entrepreneur rate, which reveals that the impact of FDI on GDP requires the presence of B2B entrepreneurs in the economy. Similarly, Audretsch and Keilbach (2007) find that compared to general entrepreneurship, the capital parameter increases in magnitude and significance in the presence of high-tech or ICT entrepreneurship.

The impact of entrepreneurial capital on the per capita GDP is positive and highly significant. With respect to its average value, the per capita GDP rises $0.49 \%$ (or $0.56 \%$ ) for each additional point in the entrepreneurial rate (or B2B entrepreneur rate). In the case of the Mexican economy, the existence of 19.92 entrepreneurs for every 1000 inhabitants contributes nearly $10 \%(=0.49 \times 19.92)$ of the per capita GDP, from which 2.2 percentage points correspond to $\mathrm{B} 2 \mathrm{~B}$ entrepreneur activity. To achieve a greater contribution to the economy from entrepreneurs, higher degrees of specialization or, in general, an increase in 
productivity would be required. It is believed that a better availability of capital in society will have a positive effect on income levels. In particular, it is thought that in a given economy, greater entrepreneurial capital endowment increases the average income. Table 6 shows the contribution of the entrepreneur rate to the per capita GDP, disaggregating the impact of B2B entrepreneurs. It reports an estimation of the percentage increase in per capita GDP in quartile 1 to illustrate the income difference between the lower (quartile 1) and the medium and the high (quartiles 2,3, and 4) income regions.

Table 5 Response of GDP per capita to an Impact From:

\begin{tabular}{lll}
\hline $\begin{array}{l}\text { Total Entrepreneurs } \\
\text { per 1,000 inhab. }\end{array}$ & 606.4 & \\
B2B Entrepreneurs & $(4.87)^{* * *}$ & 696.1 \\
per 1,000 inhab. & & $(3.23)^{* * *}$ \\
\hline Regressors including & & $(+)^{* * *}$ \\
$\quad$ R\&D & $(+)^{* * *}$ & $(+)^{* * *}$ \\
Human capital & $(+)^{* * *}$ & $(+)^{*}$ \\
FDI & $(+)$ & {$[0.000]$} \\
\hline Wald test & {$[0.000]$} & {$[1.000]$} \\
Sargan test & {$[1.000]$} & {$[0.0403]$} \\
First-order serial correlation & {$[0.0339]$} & {$[0.8094]$} \\
Second-order serial correlation & {$[0.6464]$} & 288 \\
Observations & 288 & 32 \\
Entities & 32 & \\
\hline
\end{tabular}

Authors' calculations. Source: See Table 1.

Notes: ***indicates that a coefficient is significant at the $1 \%$ level, $* *$ significant at the $5 \%$ level, $*$ significant at the $10 \%$ level. Numbers in square brackets indicate p-values. Stata GMM system estimator. Robust std error. Arellano-Bover/Blundell-Bond linear dynamic panel data estimation. Predetermined: R\&D, Human Capital, FDI.

In the case of Mexico, it is confirmed that part of the income gap is due to the different allocations of entrepreneurial capital, especially among the regions that comprise quartiles 1 , 2, and 3. It is also highlighted that in the highest quartile, the income difference is not due to a different capital allocation but instead to composition. For example, it can be assessed that the regions of quartile 1 may have a $4.6 \%$ higher per capita income if they had the same entrepreneurship rate as quartile 3. Qualitatively, quartile 4 registers a larger proportion of B2B entrepreneurs, although quartiles 3 and 4 register similar rates of total entrepreneurship. Overall, we find that with data from the Mexican economy, greater entrepreneurial capital availability increases the population's income levels. The largest income increase, between quartiles 3 and 4 , is not due to a larger number of entrepreneurs but instead to a change in their composition towards B2B entrepreneurs. 
Table 6. GDP and Entrepreneurs

\begin{tabular}{lcccc}
\hline Panel A. Mean Values & Q1 & Q2 & Q3 & Q4 \\
\hline GDP per capita , MXP, 2010=100 & 58194 & 80790 & 105218 & 159255 \\
$\quad$ Increase & n.a & $39 \%$ & $30 \%$ & $51 \%$ \\
\hline Total Entrepreneurs (per 1,000 inhab.) & 17.2 & 19.2 & 21.7 & 21.5 \\
$\quad$ Difference & n.a. & 2.0 & 2.4 & -0.1 \\
\hline B2B Entrepreneurs (per 1,000 inhab.) & 3.3 & 3.8 & 4.2 & 4.5 \\
$\quad$ Difference & n.a. & 0.5 & 0.4 & 0.3 \\
\hline
\end{tabular}

Authors' calculations. Source: See Tables 1 and 5. Note: n.a. = Not applicable.

Panel B. Increase in GDP per capita Due to a Higher Rate of Entrepreneurs

\begin{tabular}{cccc}
\hline & Q1-Q2 & Q1-Q3 & Q1-Q4 \\
\hline Total & $2.12 \%$ & $4.65 \%$ & $4.51 \%$ \\
B2B & $\beta_{E}(19.2-17.2) / y_{1}$ & $=\beta_{E}(21.7-17.2) / y_{1}$ & $=\beta_{E}(21.5-17.2) / y_{1}$ \\
\hline \multirow{2}{*}{$0.55 \%$} & $1.02 \%$ & $1.43 \%$ \\
& $=\beta_{S}(3.8-3.3) / y_{1}$ & $=\beta_{S}(4.2-3.3) / y_{1}$ & $=\beta_{S}(4.5-3.3) / y_{1}$ \\
\hline
\end{tabular}

Note: Increase $_{i}=100 \times\left[\beta_{i} \times\left(E_{k}-E_{1}\right)\right] / y_{1}$, where $i=$ total, $B 2 B_{i} \beta=d y / d E$,

$E=$ Rate of Employers, $k$-quartile $=1,2,3,4, y=$ GDP per capita.

\section{Discussion}

In the well-known article by Utterback \& Abernathy (1975), the authors define a product innovation as a new technology or a combination of technologies introduced commercially to meet a user or market need (p. 642). They claim that product innovation tends to be driven or stimulated by new market needs and opportunities (p. 643). Their definition is consistent with the guidelines of the Oslo Manual (OECD, 2005), where product innovation is defined as a good or service that is new or significantly improved. The purpose of this study was not to determine the type of innovation of FDI firms but to analyze the impact of these firms on entrepreneurs.

We consider that B2B entrepreneurs, under the influence of FDI firms, contribute mainly process innovations (i.e., significant changes in techniques, equipment, or software). We think product innovations happen only in young firms or in a sporadic manner. We also consider that the FDI is more closely associated with the market opportunities than the patents. Meza (2016) finds evidence that in Mexico, competition and export pressures are associated with cost reduction processes. Two figures are relevant and consistent with our results: i) maquiladora 
firms are $67 \%$ less likely to innovate in products than non-maquiladora firms, and ii) firms that make innovation efforts or have a patent license are $162 \%$ more likely to innovate in products (Meza, 2016). Therefore, we believe that patenting activity is more strongly associated with product innovations, while FDI is more strongly associated with process innovation.

We found in subnational data that innovating activities do not promote the emergence of all types of entrepreneurs, but only the B2B type, whose members are more productive than the $\mathrm{B} 2 \mathrm{C}$ type. The regions of the country with higher income (quartiles 3 and 4) show the highest rates of overall entrepreneurs. Hence, we find that the more entrepreneurs there are in a region, the higher the GDP per capita. The difference between quartiles 3 and 4 is that the regions with higher income (quartile 4) have more B2B entrepreneurs. We find that the key variable for overall entrepreneurs is GDP (business opportunities proxy), but B2B entrepreneurs also respond to uncertainty, which is an implicit component of innovation. The estimates show that entrepreneurs and the FDI have a jointly significant influence on the GDP.

In addition to the FDI, we used patent count in order to determine the innovative capacity of the ecosystem. Assuming that the creation of patents requires capacities and knowledge, we would expect patents to promote product innovations more frequently than does FDI (Meritt, 2007; Meza, 2016). The econometric estimate shows a positive coefficient of the patents but only at $10 \%$ significance. Our interpretation of the findings is that inward FDI in Mexico stimulates the emergence of startups and promotes process innovation. This evidence is not contradictory to that reported by Cabral et al (2014), who, using sectoral manufacturing data from Mexico, find that in the post-NAFTA era, innovation efforts (R \& D) result in faster employment growth compared to production growth.

Additionally, there is weak evidence from the patents indicator that there may be product innovations of greater complexity, although they are not generalized (Meritt, 2007). According to Rouvinen (2002) and Faria \& Lima (2009), it is simplistic to talk about innovative firms because although product and process innovations are closely related, they are driven by different factors: process innovations benefit from capital embodied technology, whereas product innovations require disembodied forms of technology. Consequently, there is a need for different interpretations of the type of innovation caused by FDI and patents. In this regard, Germán-soto et al (2009) conclude that Mexico is in a stage of technological learning and adaptation of new technologies, and they show that innovation (i.e., patents) depends on the availability of FDI and human capital.

One of the limitations of our study is that the information on entrepreneurs comes from a household survey, which provides an aggregated perspective. This limitation, however, is counteracted by the fact that we gain perspective on Mexico's situation in the last decade, which allows us to implement an efficient estimation technique such as the dynamic panel model. Once we have identified the positive influence of the FDI and the patents on the creation of B2B firms, we need further analysis to detect the types of entrepreneurs and their socioeconomic level in order to offer suitable policies. For the estimates presented here, we used the data of the total FDI, but the analysis can also be performed with greenfield FDI or by means of separating the FDI according to the industry, attempting to isolate the effect of FDI on tourism, which is very important in some regions. In the data panel, we tried to ensure the largest possible number of observations in time, but this prevented us from including other explanatory variables, such as firm financing or subnational exports. Therefore, these are preliminary findings inasmuch as we corroborate the robustness of the coefficients with the inclusion of other variables. 


\section{Conclusions}

It is generally accepted that entrepreneurs are the mechanism that converts innovation into economic growth. The goal of this paper was to evaluate whether greater innovation activity offers more business opportunities, creating groups of entrepreneurs and growth. We found that innovative activity does not promote all types of entrepreneurship, but only the B2B type, i.e., entrepreneurships with other firms or intermediaries as clients. An important feature of the B2B market is that the buyer is often larger than the seller, which would lead us to believe that we have found that process innovation that increases efficiency. To measure the innovative capacity, we used patent counts and FDI. It has been found that the impact of innovative patent activity on the rate of entrepreneurship is positive only for B2B entrepreneurs. Foreign direct investment (FDI) per capita was used as a second variable of innovation activity. Again, the impact was positive only for B2B entrepreneurs.

The estimation was conducted through a two-step estimator with a dynamic panel of robust standard errors. Per capita income, the informality rate, and an indicator of opportunity costs were used as control variables. Indeed, a greater informality rate promotes both B2B and consumer market entrepreneurship at the $10 \%$ significance level. Overall, it was found that the opportunity cost of being an entrepreneur was a more relevant determinant than per capita income. It could be expected that in an economy of low or medium technological development, there is no systematic link between innovation activity and the emergence of new firms. However, in the case of Mexico, there is evidence that in the group of B2B entrepreneurs, the patent rate and FDI will generate new ventures. This result is consistent with the theoretical proposal that new businesspeople will enter a market when they find new knowledge or new technologies with business potential. These findings contribute to the literature on entrepreneurs and innovation in developing countries.

The evidence also helps establish that these new businesspeople have better skills and better managing capacities than average entrepreneurs, allowing for the satisfaction of business market requirements and contributing to a greater extent to per capita income. Our results show that establishing innovation activities, in addition to direct benefits, has a positive externality in the group of B2B entrepreneurs. Thus, we recommended taking advantage of existing capital with additional guidelines for developing suppliers for foreign capital firms and incentives to build technology-based firms.

\section{References}

Acs, Z. J., Anselin, L., \& Varga, A. (2002). Patents and innovation counts as measures of regional production of new knowledge. Research policy, 31(7), 1069-1085. https://doi.org/10.1016/s0048-7333(01)00184-6

Amaghouss, J., \& Ibourk, A. (2013). Entrepreneurial Activities, Innovation and Economic Growth: The Role of Cyclical Factors: Evidence from OECD Countries for the Period 2001-2009. International Business Research, 6(1), 153. https://doi.org/10.5539/ibr.v6n1p153

Andersson, S. (2006). International growth strategies in consumer and business-to-business markets in manufacturing and service sectors. Journal of Euromarketing, 15(4), 35-56. https://doi.org/10.1300/j037v15n04_03

Arellano, M., \& Bond, S. (1991). Some tests of specification for panel data: Monte Carlo evidence and an application to employment equations. The Review of Economic Studies, 58(2), 277-297. https://doi.org/10.2307/2297968 
Arellano, M., \& Bover, O. (1995). Another look at the instrumental variable estimation of error-components models. Journal of econometrics, 68(1), 29-51. https://doi.org/10.1016/0304-4076(94)01642-d

Audretsch, D. B., \& Keilbach, M. (2007). The Theory of Knowledge Spillover Entrepreneurship. Journal of Management Studies, 44(7), 1242-1254. https://doi.org/10.1111/j.1467-6486.2007.00722.x

Audretsch, D. B., Carree, M. A., \& Thurik, A. R. (2001). Does Entrepreneurship Reduce Unemployment?. Tinbergen Institute Discussion Paper Series, (TI 01-074/3).

Barbosa, N., \& Eiriz, V. (2009). The role of inward foreign direct investment on entrepreneurship. International Entrepreneurship and Management Journal, 5(3), 319-339. https://doi.org/10.1007/s11365-007-0050-3

Beverland, M. B., Ewing, M. T., \& Matanda, M. J. (2006). Driving-market or market-driven? A case study analysis of the new product development practices of Chinese business-to-business firms. Industrial Marketing Management, 35(3), 383-393. https://doi.org/10.1016/j.indmarman.2005.02.008

Block, J. H., Thurik, R., \& Zhou, H. (2013). What turns knowledge into innovative products? The role of entrepreneurship and knowledge spillovers. Journal of Evolutionary Economics, 23(4), 693-718. https://doi.org/10.1007/ s00191-012-0265-5

Blundell, R., \& Bond, S. (1998). Initial conditions and moment restrictions in dynamic panel data models. Journal of econometrics, 87(1), 115-143. https://doi.org/10.1016/s0304-4076(98)00009-8

Cabral, R., \& González, F. J. (2014). Gasto en investigación y desarrollo y productividad en la industria manufacturera mexicana. Estudios Económicos, 27-55.

Cameron, A. C. and Pravin K. Trivedi (2009) Microeconometrics Using Stata, Stata Press, Texas

Chatterji, A., Glaeser, E., \& Kerr, W. (2014). Clusters of Entrepreneurship and Innovation. Innovation Policy and the Economy, 14(1), 129-166. https://doi.org/10.3386/w19013

Economic Comission for Latin America -ECLAC- (2014) Economic Survey of Latin America and the Caribbean: Challenges for sustainable growth in a new external environment [Estudio Económico de América Latina y el Caribe: Desafíos para la sostenibilidad del crecimiento en un nuevo contexto externo], UN- ECLAC.

Estrin, S. \& Mickiewicz, T. (2012) Shadow Economy and Entrepreneurial Entry. Review of Development Economics, 16(4), 559-578. https://doi.org/10.1111/rode.12004

Fagerberg, J. (2005) Innovation: A Guide to the Literature in Fagerberg, J., Mowery, D. C., \& Nelson, R. R. (Eds) The Oxford handbook of innovation, Oxford University Press

Faria, P., \& Lima, F. (2009). Firm decision on innovation types: Evidence on product, process and organizational innovation. In Druid Summer Conference, Denmark.

Gentry, W. M., \& Hubbard, R. G. (2000). Tax policy and entrepreneurial entry. American Economic Review, 9 (2), 283287. https://doi.org/10.1257/aer.90.2.283

Germán-Soto, V., Gutiérrez Flores, L., \& Tovar Montiel, S. H. (2009). Factores y relevancia geográfica del proceso de innovación regional en México, 1994-2006. Estudios Económicos, 225-248.

Glaeser, E. L., \& Resseger, M. G. (2010). The complementarity between cities and skills. Journal of Regional Science, 50(1), 221-244. https://doi.org/10.1111/j.1467-9787.2009.00635.x

Global Entrepreneurship Monitor -GEM-, Key Indicators, Disponible en: http://www.gemconsortium.org/data/key-indicators Consultado en: 15/01/19

Kato-Vidal, E. L. (2015). Uncertainty, profitability, and investment in Mexico. Nova Scientia, 7(14), 474-494. https:// doi.org/10.21640/ns.v7i14.36

Lemarchand, G. A. (2015) "Latin America" in Unesco Science Report Towards 2030, Unesco Publishing, pp. 174-209

Meritt Tapia, H. (2007). La vinculación industria-centros tecnológicos de investigación y desarrollo: el caso de los centros CONACYT de México. Análisis Económico, 22(49), 149-168.

Meza González, L., del Trabajo, S., \& Social, P. (2016). Internacionalización y creación de nuevos productos y procesos en la industria manufacturera mexicana. Estudios Económicos, 31(2), 235-263.

Modrego, F., McCann, P., Foster, W. E., \& Olfert, M. R. (2015). Regional entrepreneurship and innovation in Chile: a knowledge matching approach. Small Business Economics, 44(3), 685-703. https://doi.org/10.1007/s11187-0149612-2

Organisation for Economic Co-operation and Development -OECD- (2005). Oslo Manual: Guidelines for collecting and interpreting innovation data, OECD Publishing, Paris. 
Poschke, M. (2013). Who becomes an entrepreneur? Labor market prospects and occupational choice. Journal of Economic Dynamics and Control, 37(3), 693-710. https://doi.org/10.1016/j.jedc.2012.11.003

Rodríguez-Pose, A., \& Villarreal Peralta, E. M. (2015). Innovation and Regional Growth in Mexico: 2000-2010. Growth and Change, 46(2), 172-195. https://doi.org/10.1111/grow.12102

Rouvinen, P. (2002). Characteristics of product and process innovators: some evidence from the Finnish innovation survey. Applied Economics Letters, 9(9), 575-580. https://doi.org/10.1080/13504850110108102

Roper, S., \& Hewitt-Dundas, N. (2015). Knowledge stocks, knowledge flows and innovation: Evidence from matched patents and innovation panel data. Research Policy, 44(7), 1327-1340. https://doi.org/10.1016/j.respol.2015.03.003

Salunke, S., Weerawardena, J., \& McColl-Kennedy, J. R. (2013). Competing through service innovation: The role of bricolage and entrepreneurship in project-oriented firms. Journal of Business Research, 66(8), 1085-1097. https:// doi.org/10.1016/j.jbusres.2012.03.005

Stata (2013). Longitudinal-Data/Panel-Data Reference Manual, Stata Press, Texas.

United Nations Conference on Trade and Development -UNCTAD- (2015) World Investment Report 2015. Country fact Sheet: Mexico, UNCTAD.

U.S. Patent and Trademark Office - USPTO- (2015) Patent Counts By Country, State, and Year - Utility Patents, A Patent Technology Monitoring Team Report.

Utterback, J. M., \& Abernathy, W. J. (1975). A dynamic model of process and product innovation. Omega, 3(6), 639656. https://doi.org/10.1016/0305-0483(75)90068-7

Wong, P. K., Ho, Y. P., \& Autio, E. (2005). Entrepreneurship, innovation and economic growth: Evidence from GEM data. Small Business Economics, 24(3), 335-350. https://doi.org/10.1007/s11187-005-2000-1

World Economic Forum -WEF- (2015a) Leveraging Entrepreneurial Ambition and Innovation: A Global Perspective on Entrepreneurship, Competitiveness and Development, World Economic Forum and Global Entrepreneurship Monitor, WEF, Geneva.

World Economic Forum -WEF- (2015b) Methodology and Computation of the Global Competitiveness Index 20152016 in The Global Competitiveness Report 2015-2016, WEF, Geneva. 